\title{
PENGARUH PENGGUNAAN DEDAK PADI YANG DIFERMENTASI DENGAN KAPANG Trichoderma harzianum TERHADAP PERFORMA BROILER SAMPAI UMUR ENAM MINGGU
}

\author{
Nelzi Fati ${ }^{1}$
}

\begin{abstract}
An experiment was conducted to study the effect of utilization fermented rice bran as mixed in ration of broiler. In this DOC broilers strain Arbor Acress 707 were treated for 6 weeks. The rations treatments contained : A. $0 \%$ fermented rice bran, B. $10 \%$ fermented rice bran, C. $20 \%$ fermented rice bran, D. $30 \%$ fermented rice bran and E. $40 \%$ fermented fermented rice bran. The experimental designed was complety randomized design. Parameter observed were feed consumption, body weight and ration conversion.

The result of the experiment showed that utilization fermented rice bran as mixed in ration could be given up to $20 \%$ of fermented rice bran.
\end{abstract}

Key words : Body weight, Feed consumption, Fermented rice bran, Ration conversion

\section{PENDAHULUAN}

Perkembangan usaha ternak unggas memerlukan penyediaan bahan pakan yang memadai dan tidak bersaing dengan kebutuhan pangan manusia. Dalam usaha yang bergerak dibidang peternakan, pakan merupakan biaya produksi yang terbesar, dimana biaya pakan ini dapat mencapai 60-70\% dari seluruh biaya produksi sedangkan pakan selalu menjadi masalah utama selama ini karena tingginya harga pakan tersebut. Tingginya harga pakan ternak unggas terutama sekali disebabkan oleh jenis bahan pakan yang dipergunakan dalam penyusunan pakan harganya mahal seperti jagung yang pemakaiannya dalam persentase yang tinggi dalam pakan. Pakan ternak unggas sebagian disusun dari bahan pakan yang juga dikonsumsi manusia.

Untuk menekan harga pakan, maka dicari bahan konvensional yang ketersediaannya cukup sepanjang waktu dan tidak bersaing penggunaannya dengan kebutuhan manusia dan dapat dipergunakan sebagai campuran pakan ternak unggas. Salah satu bahan pakan tersebut adalah dedak padi.

Dedak padi merupakan hasil ikutan pertanian yang berasal dari limbah proses pengolahan gabah menjadi beras yang tidak dapat dikonsumsi oleh manusia dan 
tidak bersaing dalam penggunaannya. Dedak padi ini mudah didapat, murah harganya dan mempunyai kandungan protein lebih tinggi dibandingkan dengan kandungan serelia lainnya akan tetapi nilai energy metabolisme (EM) nya rendah bagi ternak unggas karena dedak padi mempunyai kandungan serat kasar yang cukup tinggi, yang mengakibatkan daya cernanya menjadi rendah. Apalagi kalau kita temukan dedak padi yang banyak sekali mengandung kulit padi (sekam) sehingga secara langsung kandungan serat kasarnya akan tinggi. Untuk itu diperlukan suatu teknologi yang dapat menurunkan kandungan serat kasar tersebut yaitu dengan cara fermentasi dengan menggunakan kapang yang menghasilkan enzim selulase.

Fermentasi dengan menggunakan jamur/kapang merupakan alternatif pengolahan terhadap bahan pakan ini karena jamur dapat merombak komponen yang sulit dicerna menjadi lebih tersedia dan meningkatkan palatabilitas pakan. Saono (1988) menyatakan bahwa, fermentasi dapat meningkatkan kandungan protein, mengurangi senyawasenyawa racun dari bahan dasar, mengubah rasa dan aroma menjadi lebih baik dan dapat menambah daya cerna sehingga nilai ekomomisnya menjadi lebih baik. Lebih lanjut Fardiaz dan Winarno (1980) menyatakan bahwa proses fermentasi dibutuhkan mikroorganisme yang dapat menghasilkan enzim-enzim untuk merombak zat-zat makanan yang terdapat dalam substrat.

Enzim yang dihasilkan pada proses fermentasi dibutuhkan untuk memecah selulosa yang secara komersil banyak diperoduksi oleh mikroba adalah selulase (1.4 $\beta$ D-glucan 4 glucanohydrolase). Enzim selulase ini banyak juga dihasilkan dari kapang genus Trichoderma. Wiseman (1981) menyatakan bahwa kapang dari genus Trichoderma menghasilkan enzim-enzim perombak selulosa yang lebih lengkap dibandingkan jamur lainnya.

Hasil penelitian Refnita (1990), penggunaan dedak padi yang difermentasi dengan kapang Aspergillus niger yang optimal dalam ransum adalah $22 \%$ pada periode starter. Sedangkan menurut Rasyaf (1990) penggunaan dedak padi dalam ransum adalah $20 \%$, hal ini disebabkan karena keterbatasan dedak padi itu sendiri yang mengandung serat kasar yang tinggi.

Berdasarkan uraian diatas, maka perlu suatu penelitian untuk mengetahi pengaruh penggunaan dedak padi yang difermentasi dengan kapang Trichoderma harzianum dalam ransum terhadap performa broiler.

\section{METODE PENELITIAN}

\section{A. Tempat dan Waktu Penelitian}

Penelitian dilakukan di Kandang Percobaan Fakultas Peternakan Universitas Andalas, Padang. 


\section{B. Bahan dan Alat}

Percobaan ini dilaksanakan selama enam minggu menggunakan 100 ekor broiler umur satu hari (DOC) "Strain CP 707" yang berasal dari PT. Charoen Pokphand Jaya Farm Medan. Bahan makanan sebagai ransum broiler terdiri dari dedak padi fermentasi, dedak padi, bungkil kedelai, tepung ikan, premix A dan minyak nabati.

Alat yang digunakan yaitu kandang sistem cage dan peralatan lainnya seperti : timbangan O'Haus dengan kapasitas 2610 gram, alat-alat tulis, peralatan lainnya seperti : pisau, kertas dan plastik.

\section{Rancangan Percobaan}

Percobaan ini dilakukan dengan menggunakan Rancangan Acak Lengkap dengan lima perlakuan (A, B, C, D dan E). Setiap perlakuan diulang sebanyak lima kali. Masing-masing perlakuan diacak untuk setiap petak kandang. Pada setiap petak kandang ditempatkan secara acak banyak 4 ekor ayam sebagai unit percobaan.

Untuk mengetahui pengaruh setiap perlakuan dihitung dengan Sidik Ragam, sedangkan untuk melihat respon perlakuan terhadap peubah yang diamati digunakan uji DNMRT.

\section{Pelaksanaan Penelitian}

\section{Persiapan Dedak Padi Fermentasi}

Fermentasi dedak padi dilakukan dalam kantong plastic yang dapat menghasilkan biomassa dedak padi dengan ukuran kantong plastik $2 \mathrm{~kg}$ diisi dedak padi sebanyak 250 gram dengan air sebanyak $150 \mathrm{ml}(5: 3)$ dan ditambahkan larutan nutrient (sebagai nutrient dan misalnya adalah $\mathrm{MgSO}_{4} .7 \mathrm{H}_{2} \mathrm{O} 0,25 \mathrm{~g}$, $\mathrm{FeSO}_{4} 7 \mathrm{H}_{2} \mathrm{O} 0,1 \mathrm{mg}, \mathrm{MnSO}_{4} 4 \mathrm{H}_{2} \mathrm{O} 0,1 \mathrm{mg}$, $\mathrm{KH}_{2} \mathrm{PO}_{4} 1 \mathrm{~g}, \quad \mathrm{ZnSO}_{4} .7 \mathrm{H}_{2} \mathrm{O} \quad 0,1 \mathrm{mg}$, thyamin hydroclorid $12,5 \mathrm{mg}$, urea $5 \mathrm{~g}$ (Brooke et al, 1969) sebanyak $15 \mathrm{ml}$, kemudian disterilisasi dengan autoclave selama 30 menit $\left(121^{0}, 1\right.$ atm) dibiarkan dingin pada suhu kamar dan diinokulasi dengan inokulum sebanyak $7 \%$ dan diinkubasi pada suhu kamar selama empat hari. Produk yang berupa biomassa dedak padi tersebut selanjutnya dikeringkan dibawah sinar matahari sampai kadar air mencapai sekitar $10 \%$ dan akhirnya produk fermentasi dapat dipergunakan sebagai bahan pakan ternak broiler.

Sebagai perlakuan dalam percobaan ini ditingkat pemberian dedak padi fermentasi adalah sebanyak 0,10,20, 30 dan $40 \%$ dalam ransum.

Penyusunan Ransum

Bahan makanan yang digunakan dalam penyusunan ransum terdiri dari jagung kuning, dedak padi yang difermentasi oleh kapang Trichoderma harzianum, bungkil kedelai, dedak padi, tepung ikan, premix A dan minyak nabati yang telah dianalisis terlebih dahulu kandungan zat-zat makanannya seperti tercantum pada Tabel 1. Ransum percobaan diaduk sendiri sesuai dengan komposisi bahan makanan penyusun ransum percobaan seperti yang tercantum pada Tabel 2, sedangkan komposisi zat- 
zat makanan ransum percobaan tertera diberikan ad libitum.

pada Tabel 3. Ransum dan air minum

Tabel 1. Komposisi Zat-zat makanan dan energy metabolisme bahan makanan penyusun ransum percobaan ( Berdasarkan As fed)

\begin{tabular}{|l|l|l|l|l|l|l|}
\hline Bahan makanan & $\begin{array}{l}\text { Protein } \\
(\%)\end{array}$ & $\begin{array}{l}\text { Lemak } \\
(\%)\end{array}$ & $\begin{array}{l}\text { S. Kasar } \\
(\%)\end{array}$ & Ca (\%) & P (\%) & EM* \\
\hline Jagung & 8,12 & 2,96 & 1,82 & 0,21 & 0,17 & 3562,89 \\
\hline Bungkil kedelai & 39,70 & 3,25 & 5,82 & 0,52 & 0,57 & 3165,55 \\
\hline Dedak halus & 8,74 & 7,08 & 18,90 & 0,37 & 0,3 & 1579,68 \\
\hline Dedak fermentasi & 14,66 & 9,25 & 14,81 & 0,46 & 1,5 & 1907,49 \\
\hline Tepung ikan & 56,01 & 5,60 & 2,29 & 4,14 & 1,67 & 3230,06 \\
\hline Minyak kelapa & - & 100 & - & - & - & 8300,00 \\
\hline Premix A & - & - & - & - & - & - \\
\hline
\end{tabular}

Ket: *Hasil perhitungan berdasarkan NRC (1994)

Sumber : Laboratorium Gizi Dasar Fakultas Peternakan Universitas Andalas (1996)

Tabel 2. Komposisi Bahan Makanan Ransum Percobaan

\begin{tabular}{|l|l|l|l|l|l|}
\hline \multirow{2}{*}{ Bahan Makanan } & \multicolumn{5}{|c|}{ Perlakuan } \\
\cline { 2 - 7 } & A & B & C & D & E \\
\hline Jagung & 50 & 53 & 45 & 37 & 29 \\
\hline Bungkil kedelai & 22 & 20 & 18 & 16 & 14 \\
\hline Dedak halus & 10 & - & - & - & - \\
\hline Dedak fermentasi & 0 & 10 & 20 & 30 & 40 \\
\hline Tepung ikan & 16,5 & 16,5 & 16,5 & 16,5 & 16,5 \\
\hline Minyak kelapa & 2 & - & - & - & - \\
\hline Premix A & 0,5 & 0,5 & 0,5 & 0,5 & 0,5 \\
\hline Jumlah & 100 & 100 & 100 & 100 & 100 \\
\hline
\end{tabular}

Perhitungan berdasarkan Tabel 1

Tabel 3. KOmposisi zat-zat makanan dalam ransum percobaan

\begin{tabular}{|l|l|l|l|l|l|}
\hline \multirow{2}{*}{ Zat Makanan } & \multicolumn{5}{|c|}{ Perlakuan } \\
\cline { 2 - 6 } & \multicolumn{1}{|c|}{$\mathrm{A}$} & \multicolumn{1}{c|}{ B } & C & \multicolumn{1}{c|}{ D } & \multicolumn{1}{c|}{ E } \\
\hline Protein $(\%)$ & 22,90 & 22,95 & 22,97 & 22,99 & 23,00 \\
\hline Lemak (\%) & 4,82 & 4,07 & 4,69 & 5,30 & 5,93 \\
\hline Serat Kasar (\%) & 4,82 & 4,12 & 5,50 & 6,86 & 8,23 \\
\hline Ca (\%) & 0,92 & 0,94 & 0,95 & 0,98 & 1,00 \\
\hline P tersedia (\%) & 0,35 & 0,36 & 0,41 & 0,35 & 0,35 \\
\hline ME (KKal/Kg) & 2892,45 & 2966,68 & 2924,44 & 2870,66 & 2850,06 \\
\hline
\end{tabular}

Sumber : Perhitungan Tabel 2 dan 3 


\section{HASIL DAN PEMBAHASAN}

\section{A. Konsumsi Ransum Broiler}

Konsumsi ransum yam per ekor selama percobaan tercantum pada Tabel 4. Berdasarkan Tabel 4 tersebut terlihat bahwa rataan konsumsi ransum broiler perekor yang tertinggi dari taraf pemakaian dedak padi yang difermentasi dengan kapang Trichoderma harzianum diperoleh pada broiler yang diberi pakan yang mengandung $10 \%$ dedak padi fermentasi (B), diikuti berturt-turut oleh ayam yang mengkonsumsi pakan yang mengandung $0 \%$ (A), 20\% (C), 30\% (D) dan $40 \%$ dedak padi fermentasi (E).

Penggunaan dedak padi yang difermentasi dengan kapang Trichoderma harzianum Rifai terjadi peningkatan konsumsi ransum pada taraf pemakaian $10 \%$ kemudian terjadi penurunan konsumsi ransum pada taraf pemakaian $20 \%$ sampai $40 \%$ ddak padi fermentasi dalam ransum. Selain itu terlihat rataan konsumsi ransum broiler per ekor selama penelitian antara B dengan A,C, D dan E berbeda sangat nyata $(\mathrm{P}<0,01)$ tetapi antara konsumsi ransum $\mathrm{A}, \mathrm{C}, \mathrm{D}$ dan $\mathrm{E}$ tidak berbeda nyata $(P>0,05)$. Hal ini terjadi karena dedak padi yang telah difermentasi, mempunyai kandungan protein yang lebih tinggi dibandingkan dengan dedak padi yang tidak difermentasi dengan kapang Trichoderma harzianum, dan mempunyai kadar serat kasar yang masih cukup tinggi yaitu $17,5 \%$ yang menyebabkan serat kasar dalam ransum menjadi tinggi pada taraf pemakaian dedak padi fermentasi yang tinggi.

Rendahnya konsumsi ransum dengan meningkatnya taraf pemakaian dedak padi fermentasi dalam ransum, secara tak langsung kandungan serat kasar dalam ransum meningkat sehingga laju pengosongan isi alat pencernaan menjadi lambat dan memberikan rasa kenyang pada ternak broiler, sehingga jumlah ransum yang dikonsumsi menjadi berkurang . Rasa kenyang ini ditimbulkan oleh selulosa yang terdapat dalam dedak fermentasi. Hal ini sesuai dengan pendapat Anggorodi (1985) bahwa selulosa hanya berfungsi sebagai bulk (pengenyang) bagi ternak unggas. Hasil ini didukung juga oleh hasil penelitian Koswara (1983), bahwa tingkat pemakaian dedak padi fermentasi $40 \%$ dalam ransum nyata menurunkan konsumsi dibandingkan dengan kontrol. 
Tabel 4. Rataan performa broiler selama enam minggu penelitian

\begin{tabular}{|l|l|l|l|}
\hline $\begin{array}{l}\text { Perlakuan dedak } \\
\text { padi fermentasi }\end{array}$ & $\begin{array}{l}\text { Konsumsi ransum } \\
\text { (g/ekor) }\end{array}$ & $\begin{array}{l}\text { Pertambahan berat } \\
\text { badan (g/ekor) }\end{array}$ & Konversi ransum \\
\hline A $(0 \%)$ & $3209,77^{\mathrm{b}}$ & $1551,97^{\mathrm{a}}$ & $2,10^{\mathrm{a}}$ \\
\hline B $(10 \%)$ & $3347,10^{\mathrm{a}}$ & $1591,01^{\mathrm{a}}$ & $2,11^{\mathrm{a}}$ \\
\hline C $(20 \%)$ & $3220,82^{\mathrm{b}}$ & $1519,27^{\mathrm{a}}$ & $2,12^{\mathrm{a}}$ \\
\hline $\mathrm{D}(30 \%)$ & $3214,74^{\mathrm{b}}$ & $1387,79^{\mathrm{b}}$ & $2,32^{\mathrm{b}}$ \\
\hline E $(40 \%)$ & $3151,62^{\mathrm{b}}$ & $1271,32^{\mathrm{b}}$ & $2,46^{\mathrm{b}}$ \\
\hline
\end{tabular}

Keterangan : Huruf yang berbeda pada kolom yang sama menunjukkan perbedaan yang sangat nyata ( $\mathrm{P}$ $<0,01)$

Konsumsi ransum hasil penelitian ini berkisar 3151,62 gram - 3347,10 gram lebih tinggi dibandingkan yang dilaporkan Yesserita (1996) yaitu 2836,005 gram pada strain Arbor Acres CP 707 dipelihara secara campuran (jantan dan betina) pada broiler umur enam minggu. Sedangkan menurut Mirzah (1990) konsumsi ransum broiler strain Arbor Acress CP 707 yang dipelihara secara campuran sampai umur enam minggu adalah 3202,52 gram. Perbedaan konsumsi ransum ini mungkin disebabkan kualitas dan komposisi bahan makanan yang berbeda.

\section{B. Pertambahan Berat Badan}

Pertambahan berat badan ayam per ekor selama penelitian tercantum pada Tabel 4. Berdasarkan Tabel 4 bahwa rataan pertambahan berat badan broiler per ekor yang tertinggi didapatkan pada taraf penggunaan dedak padi yang difermentasi dengan Trichoderma harzianum adalah pada level 10\% (B) diikuti berturut-turut ayam yang mengkonsumsi ransum yang mengandung $0 \%$ (A), $20 \%$ (C), 30\% (D) dan $40 \%$ dedak padi fermentasi $(\mathrm{E})$.
Hasil uji jarak Berganda Duncan memperlihatkan bahwa pertambahan berat badan pada ransum yang mengandung $10 \%$ dedak padi fermentasi (B) berbeda nyata $(\mathrm{P}>0,05)$ dengan ransum yang mengandung $0 \%$ (A) dan $20 \%$ dedak padi fermentasi (C) dalam ransum dan berbeda sangat nyata $(\mathrm{P}<0,01)$ dengan ransum yang mengandung $30 \%$ (D) dan $40 \%$ dedak padi fermentasi (E) dalam ransum. Ransum yang mengandung 30\% (D) dan $40 \%$ dedak padi fermentasi (E) dalam ransum sangat nyata $(\mathrm{P}<0,01)$ lebih rendah pertambahan berat badannya dibandingkan dengan ransum yang mengandung 0\% (A), 10\% (B) dan $20 \%$ dedak padi yang difermentasi (C) dalam ransum.

Terjadinya penurunan berat badan broiler dengan semakin meningkatnya taraf pemakaian dedak padi fermentasi dalam ransum diduga dari tingginya serat kasar dalam ransum yang tidak dapat dicerna ayam. Walaupun kapang Trichoderma harzianum mengeluarkan enzim (1.3) $\beta$ glukanase yang dapat menurunkan serat kasar padi dari 21,65\% menjadi $17,5 \%$ ternyata dedak padi yang 
digunakan sampai taraf 30\% dan $40 \%$ dalam ransum terhitung serat kasarnya $6,86 \%$ dan $8,23 \%$ yang berpengaruh sangat nyata $(\mathrm{P}<0,01) \quad$ terhadap pertambahan berat badan. Lebih rendahnya pertambahan berat badan pada pemakaian dedak padi fermentasi dengan taraf tinggi disebabkan salah satu penyebabnya adalah kandungan serat kasar yang tinggi. Jadi ransum lebih bersifat sebagai bulk. Menurut Parnell (1957) bahwa bila anak ayam belum begitu baik mencerna serat kasar ransum jangan lebih 5\% . Ditambahkan oleh Siregar et al (1980)bahwa terdapatnya serat kasar yang tinggi dalam ransum dan dalam batas-batas tertentu akan menghambat pertumbuhan. Selanjutnya Panda dan Combs (1950) melaporkan bahwa penambahan serat kasar menyebabkan energy produktif ransu lebih rendah sehingga dapat menekan pertumbuhan. Kemungkinan lainnya di dalam ransum dedak padi fermentasi terdapat zat kimiawi khusus (antibiotik) yang dihasilkan sewaktu proses fermentasi berlangsung oleh kapang Trichoderma harzianum yang menyebabkan pertambahan berat badan menjadi rendah dengan taraf pemakaian dedak padi fermentasi yang tinggi dalam ransum. Seperti yang dinyatakan Well (1986), bahwa Trichoderma harzianum $s p$. Dapat memproduksi antibiotik. Selanjutnya dijelaskan oleh Anggorodi (1985) bahwa penggunaan antibiotik untuk unggas dalam konsentrasi yang rendah, sebab penggunaan antibiotik yang berlebihan berakibat kurang baik terhadap ternak tersebut.

Hasil penelitian ini ternyata tingkat pemakaian dedak padi fermentasi hanya $20 \%$, hal ini tidak sesuai dengan hasil penelitian Refnita (1990) yang dapat menggunakan dedak padi sampai 50\% dalam ransum dimana $40 \%$ dedak padi difermentasi dengan Aspergillus niger dan $60 \%$ dedak padi tanpa fermentasi dan pertambahan berat badan optimal dicapai pada penggunaan dedak padi fermentasi $22 \%$ dalam ransum, hal ini terjadi karena dedak padi yang digunakan dalam penelitian ini mengandung serat kasar $17,5 \%$ setelah fermentasi dan $21,65 \%$ sebelum fermentasi sedangkan Refnita (1990) menggunakan dedak padi dengan serat kasar setelah fermentasi $10,12 \%$ dan $7,61 \%$ sebelum fermentasi.

Pertambahan berat badan pada penelitian ini berkisar1271,32 gram1591,01 gram lebih tinggi dibandingkan yang dilaporkan Yesserita (1996) yaitu 910,73 gram pada strain Arbor AP 707 yang dipelihara secara campuran (jantan dan betina) pada broiler umur enam minggu. Sedangkan menurut Mirzah (1990) pertambahan berat badan broiler strain Arbor AP 707 yang dipelihara secara campuran sampai umur enam minggu adalah 1509,86 gram. Perbedaan dari segi pertambahan berat badan ini mungkin disebabkan oleh kualitas dan komposisi bahan makanan yang berbeda.

\section{Konversi Ransum}

Konversi ransum ayam per ekor selama percobaan tercantum pada Tabel 4. Berdasarkan Tabel 4 tersebut terlihat 
bahwa rataan konversi ransum broiler per ekor yang tertinggi dari taraf pemakaian dedak padi yang difermentasi dengan kapang Trichoderma harzianum diperoleh pada broiler yang diberi ransum yang mengandung 40\% dedak padi fermentasi (E) diikuti berturut-turut oleh ayam yang mengkonsumsi ransm yang mengandung 30\% (D), $20 \%$ (C), 10\% (B) dan $0 \%$ dedak padi fermentasi (A).

Konversi ransum pada taraf pemakaian dedak padi fermentasi 0\% (A) tidak berbeda nyata $(\mathrm{P}>0,05)$ dengan pemakaian dedak padi fermentasi $10 \%$ (B) dan $20 \%$ (C) dalam ransum, berbeda sangat nyata $(\mathrm{P}<0,01)$ dengan pemakaian dedak padi fermentasi $30 \%$ (C) dan $40 \%$ (D) dalam ransum. Disini dapat dilihat dengan meningkatnya pemakaian dedak padi fermentasi dalam ransum maka kadarserat kasar dalam ransum maka kadar serat kasar dalam ransum juga meningkat sehingga berdampak pada penurunan berat badan dan konsumsi ransum, sehingga ayam kurang efisien dalam memanfaatkan ransum yang mengandung serat kasar tinggi. Sesuai dengan pernyataan Waldroup, Brussel dan Johnson (1976) bahwa serat yang tinggi dapat menghambat pertambahan berat badan serta efisiensi penggunaan ransum menjadi rendah. Hal ini ditunjang oleh Titus dan Fritz (1971) yang menyatakan pemberian serat kasar non toksik adalah $3-5 \%$, pemberian diatas ini akan menyebabkan terjadinya hambatan pertumbuhan dan efisiensi penggunaan pakan menjadi bertambah buruk, sedangkan menurut Morisson
(1979) bahwa ternak ayam mempunyai kemampuan rendah dalam mencerna serat kasar yaitu 5-7\%. Kemungkinan lain tingginya konversi ransum pada tingkat pemakaian dedak padi fermentasi 30\% (D) dan $40 \%$ (E) disebabkan zat kimiawi khusus (antibiotik) yang dihasilkan sewaktu proses fermentasi dedak padi oelh kapang Trichoderma harzianum berlangsung sehingga dengan tingginya pemakaian dedak padi fermentasi dalam ransum maka kandungan zat kimia (antibiotik) itupun meningkat yang berakibat pada penurunan berat badan dan konsumsi ransum tidak sebanding lagi.

Konversi ransum pada penelitian ini berkisar 2,07 - 2,46 lebih rendah dibandingkan dengan yang dilaporkan Yesserita (1996) yaitu 3.1 pada strain Arbor Acress CP 707 yang dipelihara secara campuran pada broiler umur enam minggu. Sedangkan menurut Mirzah (1990), konversi ransum broiler strain Arbor Acress CP 707 yang dipelihara secara campuran sampai umur enam minggu adalah 2.12 , perbedaan ini disebabkan oleh kualitas dan komposisi ransum yang berbeda.

\section{KESIMPULAN}

Hasil ini dapat disimpulkan bahwa pemberian dedak padi yang difermentasi dengan kapang Trichoderma harzianum dapat ditolerir sampai $20 \%$ dalam ransum terhadap pertambahan berat badan , konsumsi ransum dan konversi ransum.

\section{DAFTAR PUSTAKA}


Anggorodi, R. 1985. Ilmu Makanan Ternak, Kemajuan Mutakhir. Penerbit UI-Press, Jakarta.

Brooke, E.J. W.R. Stanton and. A.W. Bridge. 1969. Fermentation methods for protein enrichment of cassava. Biotech Bioeng. 11. 12711284.

Fardiaz, S. dan F.G. Winarno. 1980. Pengantar Teknologi Pangan. PT.Gramedia. Jakarta.

Koswara, D. 1983. Pengaruh peragian dedak dalam ransum terhadap penampilan ayam broiler. Karya Ilmiah Fakultas Peternakan, IPB. Bogor.

Mirzah. 1990. Pengaruh tingkat penggunaan tepung limbah udang yang diolah dan tanpa diolah dalam ransum terhadap performans ayam pedaging. Program Pascasarjana Universitas Padjajaran. Bandung.

N.R.C. 1994. Nutrient Requirement of Poultry. $9^{\text {th }}$ Ed. National Research Council. National Academy of Science, Washington.

Parnell, E. D. 1957. Profitable Poultry Production. John Willey and Sons Inc, New York.

Rasyaf, M. 1990. Bahan makanan unggas di Indonesia. Penerbit Kanisius Yogyakarta.

Refnita, 1990. Pengaruh penggunaan fermentasi dedak padi dengan kapang Aspergillus niger dalam ransum terhadap performa dan ketersediaan mineral $\mathrm{Mg}$ ayam pedaging. Fakultas Pascasarjana IPB, Bogor.
Saono. 1988. Pemanfaatan jasad renik dalam pengolahan hasil samping atau sisa produksi pertanian. LIPI. 8(4) 1-11, Jakarta.

Siregar, A.P., M. Sabrani dan Pramu s. 1980. Tekhnik Beternak Ayam Pedaging di Indonesia. Penerbit Margie Group, Jakarta.

Waldroup, P.W., W. D. Brussel and Z. B Jhonson. 1976. Attemps to control body weight gains of growing broiler breeder females with fiber diets. Pout. Sci. 55: 1118-1120.

Well, H.D. 1986. Trichoderma as Biocontrol Agent. In K.G. Mukerji and K.L,. garg (ed). Biocontrol of plant disease. CRC Press Inc, Boca Raton Florida.

Wiseman, A. 1981. Topics in Enzyme and fermentation Biotechnology. Vol. 4. Ellis. Harwood Limeted, John Will.

Yessirita, N. 1996. Kandungan gizi tepung eceng gondok (Eichhornia crassipes) yang diberi berbagai jenis perlakuan dan pengaruhnya terhadap performa ayam broiler. Program Pascasarjana Universitas Andalas. Padang.

Telah dipublised di Jurnal LUMBUNG Politeknik Pertanian Negeri Payakumbuh . Vol 3 No 2, Bulan Juli 2004. ISSN : 1412-1883. 
